\title{
Phytoregulators and Explant Size in the in vitro Culture of Malva sylvestris
}

\author{
Leyza Paloschi de Oliveira ${ }^{1}$, Cassio Geremia Freire ${ }^{2}$, Simone Silmara Werner ${ }^{3}$, Mari Inês Carissimi Boff ${ }^{1}$ \\ $\&$ Pedro Boff ${ }^{3}$ \\ ${ }^{1}$ Centro de Ciências Agroveterinárias, Universidade do Estado de Santa Catarina, Lages, Brazil \\ ${ }^{2}$ Universidade do Alto vale do Rio do Peixe, Caçador, Brazil \\ ${ }^{3}$ Empresa de Pesquisa Agropecuária e Extensão Rural de Santa Catarina, Lages, Brazil \\ Correspondence: Leyza Paloschi de Oliveira, Universidade do Estado de Santa Catarina, Centro de Ciências \\ Agroveterinárias, Av. Luiz de Camões 2090, Conta Dinheiro, CEP 88.520-000, Lages, Brazil. Tel: \\ 55-49-999-126-147. E-mail: leyza@uniarp.edu.br
}

Received: September 21, 2018

Accepted: October 28, $2018 \quad$ Online Published: December 15, 2018

doi:10.5539/jas.v11n1p388

URL: https://doi.org/10.5539/jas.v11n1p388

\begin{abstract}
In vitro propagation of plants makes it possible to accelerate the process of plant multiplication, the study of secondary metabolite production and the cultivation of biotrophic fungi. The objective of this work was to study the combination of indoleacetic acid (IAA) and benzylaminopurine (BAP) and explant sizes in in vitro multiplication of $M$. sylvestris. Five concentrations of BAP $\left(0,0.5,1.0,1.5\right.$ and $\left.2.0 \mathrm{mg} \mathrm{L}^{-1}\right)$ and two of IAA (0 and $0.5 \mathrm{mg} \mathrm{L}^{-1}$ ) were used in explants of 4 to $9 \mathrm{~mm}$ and of 14 to $23 \mathrm{~mm}$. Contaminated explants, oxidation, establishment, relative growth rate (RGR), sprouting, rooting and callus formation were evaluated. There was no interaction effect between BAP and IAA concentrations. At 28 days, explants were established at $32.76 \%$ and callus formation was $62.5 \%$ for explants associated with $0.0 \mathrm{mg} \mathrm{L}^{-1}$ of IAA. There was $32.14 \%$ establishment and $63.79 \%$ callus formation at $0.5 \mathrm{mg} \mathrm{L}^{-1}$ of IAA. Bacterial contamination at 28 days was $60.53 \%$, twice as much the amount found at 14 days, suggesting that the explants presented endogenous contamination. It was found that explant size influences the subsequent meristematic development. The use of smaller explants (4 to 9 $\mathrm{mm}$ ) allowed greater formation of calli and larger explants (14 to $23 \mathrm{~mm}$ ) allowed greater formation of shoots. In conclusion, larger explants are preferable for production of $M$. sylvestris in vitro by organogenesis while smaller ones are preferable for embryogenesis.
\end{abstract}

Keywords: micropropagation, indoleacetic acid, benzylominopurine

\section{Introduction}

Mallow or malva-sylvestris (Malva sylvestris L.) is a plant of medicinal interest with antitussive, antiseptic, anti-inflammatory, anti-osteclastogenic and antioxidant effects (Brasil, 2011; Benso, Franchin, Massarioli, Paschoal, Alencar, Franco, \& Rosalen, 2016). Medicinal plants are regularly used to heal humans and animals because they contain different metabolites of interest (Marouane, Soussi, Murat, Bezzine, \& El Feki, 2011; Prudente, Sponchiado, Mendes, Soley, Cabrini, \& Otuki, 2017). Among the compounds found in M. sylvestris, phenolics are the main components in the leaves $\left(386.45 \mathrm{mg} \mathrm{g}^{-1}\right.$ of methanolic extract), but other components with antioxidant action include flavonoids $\left(210.81 \mathrm{mg} \mathrm{g}^{-1}\right)$ and carotenoids $\left(0.19 \mathrm{mg} \mathrm{g}^{-1}\right)$, as well as high amounts of ascorbic acid in flowers $\left(1.11 \mathrm{mg} \mathrm{g}^{-1}\right.$ ) (Barros, Carvalho, \& Ferreira, 2010). Malvone A, 2-methyl-3-methoxy-5,6-dihydroxy-1,4-naphthoquinone, is a terpene present in flowers which, in addition to antimicrobial activity, can assist in the wound healing process (Pirbalouti, Yousefi, Nazari, Karimi, \& Koohpayeh, 2009). The main sugars that compose mucilage are fructose, glucose, sucrose, trehalose and raffinose (Tomoda Gonda, Shimizu, \& Yamada, 1989).

Genotype and plant part being used are important variables for chemical constitution of plants (Tabaraki, Yosefi, \& Hossein, 2012). Khatami and Ghanati (2011) used in vitro cultivation of M. negleta for callus production to evaluate the effects of flavonoids, anthocyanins and tannins on UV ray absorption. Quantification of fatty acids in callus culture of plants of the genus Malva sp. showed that M. sylvestris and M. parviflora produce significant amounts of cyclic acids e.g., cyclopropene and cycloprane, which form a biosynthetic system, whereas in other 
mallows, the largest production occurs in young seeds (Yano, Nichols, Morris, \& James, 1972).

The production system recommended for medicinal plants is based on good cultivation practices and genotypic identity that can meet market demands and provide safe access to products processed as phytotherapeutics (Embrapa, 2015).

Micropropagation is one of the options to qualify the production of seedlings and maintain their genotypic identity associated with the respective phytochemical descriptors (Rout, Samantaray, \& Dasa, 2000). According to Kintzios (2002), explants of branches and petioles of $M$. sylvestris are responsive to in vitro growth in Murashige and Skoog (1962) (MS) medium, whereas leaves did not allow formation of viable propagules in their various treatments.

Previous research on in vitro micropropagation of Malva sylvestris, using benzylominopurine (BAP) and naphthaleneacetic acid (NAA), showed higher fresh mass, plant height and number of leaves at the concentrations of $2.0 \mathrm{mg} \mathrm{L}^{-1}$ of BAP and $0.5 \mathrm{mg} \mathrm{L}^{-1}$ of NAA but without rooting, however (Filter, Freitas, \& Périco, 2014). These two growth regulators had been tested for M. sylvestris calli, and the best results were found in equimolar combinations of $9 \mu \mathrm{M}$, whereas higher concentrations negatively affected callogenesis (Kintzios, Katsouri, Peppes, \& Koulocheri, 1998). In studies with Althea rosea (Malvaceae), Tyub, Kamili \& Bhat (2016) found higher numbers of shoots after adding BAP and NAA, while rooting percentage was higher after use of IAA. In embryogenesis studies and in vitro establishment of M. sylvestris, Kintzios et al. (1998) found that there was production of callus and metabolites, including substances other than those found in in vivo tissues.

Vegetative propagation may also be useful in the phytosanitary management of $M$. sylvestris, because Puccinia malvacearum may survive in seeds, and infection may occur at the beginning of the budding of this fungus, which is the major cause of mallow leaves (Gavériaux, 2012). Kuvalekar and Gandhe (2010) found infection by Uromyces hobsoni, a fungus that causes rust, after in vitro establishment of Jasminum officinale var. grandiflorum. The occurrence of rust on M. sylvestris may compromise the quality of the plant and derived products, as well as of purity tests. Thus, leaves may present at most one (1) blister-like pustule of $P$. malvacearum teliospore per $\mathrm{cm}^{2}$ to be considered to have good quality (Brazil, 2000). On the other hand, in vitro culture of $M$. sylvestris may be an important technique for cultivation of $P$. malvacearum, a biotrophic fungus which is dependent on living tissues for survival (Agrios, 2005). In addition to contributing to the phytosanitary aspect of seedlings, micropropagation can increase uniformity and large-scale production, thus preserving the standard that increases medicinal interest and use of the plant (Grattapaglia \& Machado, 1998).

The goal of this work was to study the effect of combinations of plant growth regulators, indoleacetic acid (IAA) and benzylominopurine (BAP), and to verify the influence of plant growth regulators on the potential supply of calluses and buds for studies on Phytopathology, secondary metabolites and vegetative propagation of different sizes of explants associated with IAA in the introduction of in vitro explants of $M$. sylvestris.

\section{Method}

\subsection{Producing Matrices for Propagation and General Study Conditions}

Malva sylvestris plants were produced by planting seeds in $600 \mathrm{ml}$ expanded polystyrene (EPS) pots with Agrinobre TMX substrate and keeping them in a greenhouse at a variable temperature for three months. The seeds were selected for planting, excluding those with signs of P. malvacearum.

The experiments of introduction and multiplication of mallow were carried out at the Plant Tissue Culture Laboratory, EPAGRI (Experimental Station of EPAGRI (Agricultural Research and Extension Service Agency of Santa Catarina State, Brazil). The experiments were set up in a growth chamber where the flasks were then exposed to a 16-hour photoperiod.

The MS medium (Murashige \& Skoog, 1962) with all its salts and vitamins was used, and pH was adjusted to $5.8 \pm 0.05$ before addition of the solidifier $\left(6 \mathrm{~g} \mathrm{~L}^{-1}\right.$ Merck agar). This medium was supplemented with $30 \mathrm{~g} \mathrm{~L}^{-1}$ of sucrose and plant growth regulators prior to autoclaving, as described in the experiment on combinations of plant growth regulators and different explants and IAA concentrations, in addition to the addition of $0.5 \mathrm{mg} \mathrm{L}^{-1}$ activated carbon. The medium was poured into test tubes $(25 \times 150 \mathrm{~mm})$.

Plants with approximately 90 days of age were used as sources of explants in both experiments. To that end, herbaceous branches of mallow, containing between 30 and 60 centimeters, were excised, washed in running water containing neutral detergent and then washed three times in distilled water. 
Asepsis of explants consisted of washing and immersion in sterile distilled water in the two experiments. After this procedure, the aseptic cells were cleaned in a laminar flow chamber, using $70 \% \mathrm{v} / \mathrm{v}$ ethanol for one minute, followed by immersion for 15 minutes in sodium hypochlorite solution $(\mathrm{NaClO})$ containing $1.5 \%$ of active principle and Tween ${ }^{\circledR} 20$ at 10 drops $\mathrm{L}^{-1}$. The buds were then washed four times in sterile distilled water, and remained submerged in sterile distilled water until introduced into the medium. After introduction, the buds were kept in a growth chamber (temperature of $25 \pm 2{ }^{\circ} \mathrm{C}$ and photoperiod of 16 hours). The tubes were exposed to luminous intensity of $75 \mu \mathrm{mol} \mathrm{m} \mathrm{m}^{-2}$, provided by white and cold fluorescent lamps.

\subsection{Exp. 1 Combination of Phytoregulators in the in vitro Introduction of Mallow}

Axial buds, containing 6 to $8 \mathrm{~mm}$ and 2 or 3 leaves (Figure 1), were used as explants in the in vitro introduction. The experiment was conducted in a completely randomized design in a $2 \times 5$ factorial arrangement, with the following factors: absence of IAA and IAA $0.5 \mathrm{mg} \mathrm{L}^{-1}$ combined with five (5) levels of BAP concentration. BAP concentrations were $0 ; 0.5 ; 1.0 ; 1.5$ and $2.0 \mathrm{mg} \mathrm{L}^{-1}$ present in complete MS medium $\left(10 \mathrm{~mL}\right.$ tube $\left.\mathrm{e}^{-1}\right)$, totaling 10 treatments, with 15 replicates in each treatment. The replicates consisted of one (1) explant.

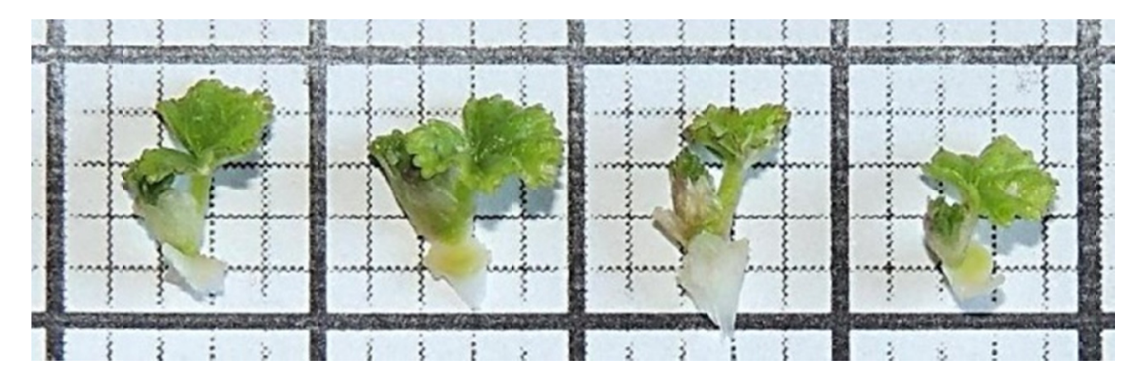

Figure 1. Axillary buds of Malva sylvestris used as explants in the in vitro introduction in Murashige and Skoog medium

Note. Smaller and larger squares correspond to 2 and $10 \mathrm{~mm}$, respectively.

\subsection{Exp. 2 Influence of Different Explant Sizes and IAA Concentrations in the Culture Medium on in vitro Introduction of Mallow}

The experiment was conducted in a completely randomized design, and consisted of a $2 \times 2$ factorial arrangement according to the explant size in use and IAA concentration in the medium. Two concentrations of IAA $\left(0\right.$ and $\left.0.5 \mathrm{mg} \mathrm{L}^{-1}\right)$ and two explant sizes, small (4 to $\left.9 \mathrm{~mm}\right)$ and large (14 to $\left.23 \mathrm{~mm}\right)$, were analyzed, as shown in Figure 2. These explants were inserted into the MS medium, containing $2.5 \mathrm{mg} \mathrm{L}^{-1}$ of BAP $(10 \mathrm{~mL}$ tube $\left.{ }^{-1}\right)$, with 4 treatments in total, with a different number of replicates: for the small types with IAA 0.0 and 0.5 $\mathrm{mg} \mathrm{L}^{-1}, 30$ and 28 explants, respectively; for large types with IAA 0.0 and $0.5 \mathrm{mg} \mathrm{L}^{-1} 29$ and 32 explants, respectively. 


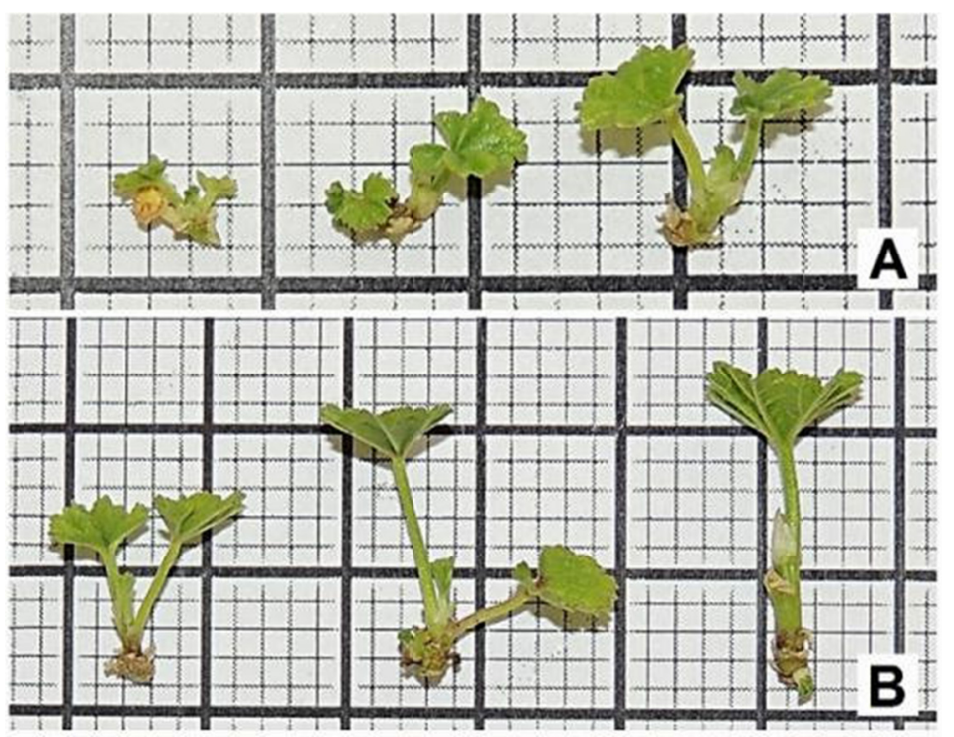

Figure 2. Axillary buds of Malva sylvestris. Small $(<10 \mathrm{~mm})$ (A) and large, $(>10 \mathrm{~mm})(B)$, used as explants in the in vitro introduction of mallow (Malva sylvestris)

Note. Smaller and larger squares correspond to 2 and $10 \mathrm{~mm}$, respectively.

\subsection{Evaluations}

In vitro evaluations of Experiment 1 were performed at 14 and 28 days for the explants. The evaluations included: count of explants showing bacterial and fungal contamination, rooting (\%), oxidation (\%) and relative growth rate (RGR) $\left(\mathrm{mm} \mathrm{mm} \mathrm{d}^{-1}\right)$. At the 28 days, number of sprouts and callus was recorded.

In Experiment 2, the evaluations performed at 14 days consisted of: number of explants with bacterial and fungal contamination, oxidation (\%), establishment (\%), RGR and number of shoots. At 28 days, the percentages of establishment, rooting, callus, RGR, discarding and number of shoots were evaluated.

Contamination by bacteria and fungi was evaluated according to the methodology described by Scherwinski-Pereira (2010). Explants that were partially or totally darkened were considered to be oxidized while the explants that were partially or totally greenish, in addition to having emitted sprouts or leaves, were considered to be established. The evaluation of adventitious root production was based on the methodology described by Grattapaglia and Machado (1998). RGR (equation 1) was calculated as described by Briggs, Kid and West (1920):

$$
\mathrm{CR}=\frac{\left(\mathrm{LnC}_{2}-\mathrm{LnC}_{1}\right)}{(\mathrm{t} 2-\mathrm{t} 1)}
$$

where, $\mathrm{Ln}$ is the natural/Napierian logarithm of the length values obtained in the different evaluations, and $\mathrm{C}_{2}$ and $\mathrm{C}_{1}$ indicate growth (in millimeters) measured at $\mathrm{t} 2$ (final) and $\mathrm{t} 1$ (initial) times, respectively.

\subsection{Data Analysis}

The bacterial and fungal contamination, oxidation, rooting, establishment, disposal and callus were analyzed by using the Binomial model with the logit function. Deviance analysis was performed with the chi-square test. The number of shoots was analyzed using the Poisson model, with a superdispersion (quasipoisson) parameter, and deviance analysis was performed with the F-test. For RGR, normal distribution was used, and the Box-Cox transformation was performed in cases where the assumptions of the model were not met; in this case, normality was verified through the Shapiro-Wilk test and homoscedasticity, using the Bartlett test. Tukey's contrasts were used to compare treatment levels using the procedure for testing linear hypotheses described by Hothorn, Bretz, and Westfall (2008). All tests were performed at the $5 \%$ level of significance. The procedures were implemented in the R (R Core Team, 2017) environment.

\section{Results and Discussion}

Average establishment of in vitro explants at 28 days reached $32.76 \%$ for BAP concentrations associated with $0.0 \mathrm{mg} \mathrm{L}^{-1}$ of IAA and $32.14 \%$ when associated with $0.5 \mathrm{mg} \mathrm{L}^{-1}$ of IAA, without interaction between treatments (Table 1). In this period, calluses were formed (Figures $3 \mathrm{C}$ and $\mathrm{D}$ ) in $62.50 \%$ of the explants at the different 
concentrations of BAP and IAA $0.0 \mathrm{mg} \mathrm{L}^{-1}$ and in $63.79 \%$ of BAP and $0.5 \mathrm{mg} \mathrm{L}^{-1}$ IAA, respectively. High percentages of callogenesis were also found by Sié et al. (2010) in Hibiscus sabdariffa L., another species of the family Malvaceae, regardless of type of explant in use and concentrations of growth regulators in use.

Table 1. Establishment and growth of Malva sylvestris explants in in vitro culture in Murashige and Skoog environments, with different concentrations of plant growth regulators, 2017

\begin{tabular}{|c|c|c|c|c|c|c|}
\hline \multirow{2}{*}{$\operatorname{IAA}\left(\mathrm{mg} \mathrm{L}^{-1}\right)$} & \multirow{2}{*}{$\mathrm{BAP}\left(\mathrm{mg} \mathrm{L}^{-1}\right)$} & \multirow{2}{*}{ EST $(\%)$} & \multirow{2}{*}{ CALLUS (\%) } & \multirow{2}{*}{ BUD (n) } & \multicolumn{2}{|c|}{$\operatorname{RGR}^{1}\left(\mathrm{~mm} \mathrm{~mm} \mathrm{~d}^{-1}\right)$} \\
\hline & & & & & $14^{\circ}$ day & $28^{\circ}$ day \\
\hline \multirow{5}{*}{0.0} & 0.0 & 50.00 & 87.50 & 1.88 & 0.013 & 0.017 \\
\hline & 0.5 & 36.36 & 63.64 & 1.73 & 0.013 & 0.018 \\
\hline & 1.0 & 18.18 & 45.45 & 1.91 & 0.016 & 0.008 \\
\hline & 1.5 & 30.77 & 53.85 & 2.54 & 0.021 & 0.015 \\
\hline & 2.0 & 33.33 & 73.33 & 2.27 & 0.031 & 0.012 \\
\hline \multirow[t]{3}{*}{ Mean } & & $32.76^{\mathrm{ns}}$ & $63.79^{\mathrm{ns}}$ & $2.10^{\mathrm{ns}}$ & $0.018 \mathrm{~b}$ & $0.014^{\mathrm{ns}}$ \\
\hline & 0.0 & 30.77 & 69.23 & 2.38 & 0.021 & 0.016 \\
\hline & 0.5 & 36.36 & 45.45 & 2.55 & 0.022 & 0.015 \\
\hline \multirow[t]{3}{*}{0.5} & 1.0 & 45.45 & 63.64 & 2.73 & 0.035 & 0.013 \\
\hline & 1.5 & 30.00 & 70.00 & 2.20 & 0.028 & 0.011 \\
\hline & 2.0 & 18.18 & 63.64 & 2.27 & 0.029 & 0.010 \\
\hline Mean & & $32.14^{\mathrm{ns}}$ & $62.50^{\mathrm{ns}}$ & $2.43^{\mathrm{ns}}$ & $0.027 \mathrm{a}$ & $0.013^{\mathrm{ns}}$ \\
\hline
\end{tabular}

Note. Means followed by the same letter in the column of each variable do not differ significantly from each other by deviance analysis ( $\mathrm{p} \leq 0.05$ ); ns: non-significant; BAP: abscisic acid; IAA: indoleacetic acid; EST: establishment; BUD: budding; RGR: relative growth rate; 1 transformed variable (lambda $=0.3$ ).

Number of shoots per explant ranged from 1.73 to 2.73 with different associations of plant growth regulators (Table 1). The RGR of the explants in the association of BAP with $0.5 \mathrm{mg} \mathrm{L}^{-1}$ of IAA was higher than that with $0.0 \mathrm{mg} \mathrm{L}^{-1}$ of IAA at 14 days, and there was no difference between the treatments performed at 28 days.

Contamination and oxidation were the major impact factors in the establishment of in vitro explants. Bacterial and fungal contamination may be endogenous or exogenous (Ray \& Ali, 2017). In the case of M. sylvestris, bacterial contamination at 28 days (Table 2$)$ was twice as much $(60.53 \%)$ the rate found at 14 days $(28.97 \%)$, suggesting that the explants had endogenous contamination. 


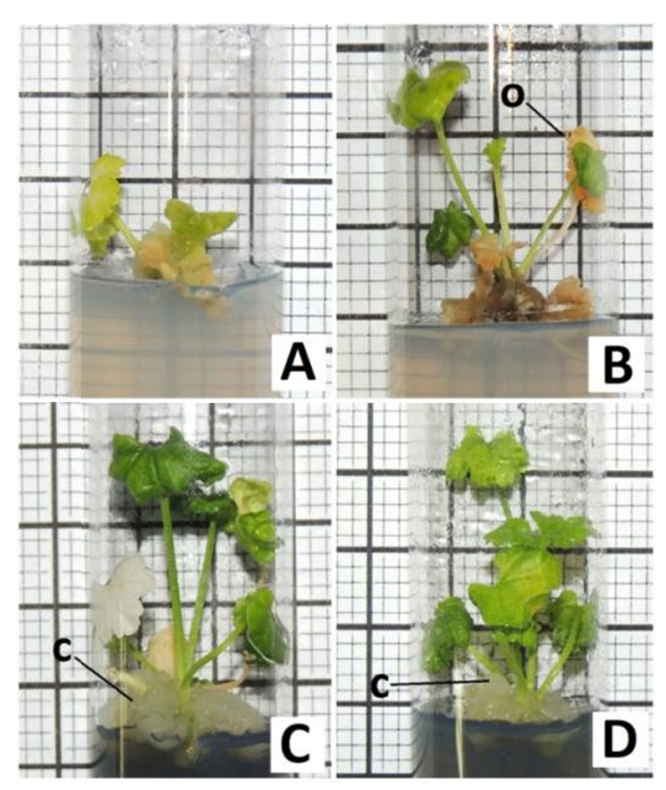

Figure 3. Malva sylvestris explants introduced in vitro in Murashige and Skoog (MS) medium supplemented with different concentrations of growth regulators, 2017

Note. Explant partially oxidized after 14 days in vitro (A); explants with some oxidized shoots (o) after 28 days in vitro (B); explants that produced calluses at the base after 28 days in vitro (C and $\mathrm{D})$; o, oxidation; c, callus. Smaller and larger squares correspond to 2 and $10 \mathrm{~mm}$, respectively.

Scherwinski-Pereira (2010) reported that in vitro cultures may develop late bacterial growth, as they often contain endophytic or fastidious microorganisms. The occurrence of endophytic microorganisms in medicinal plants has been reported in studies that were aimed at verifying whether or not there is a risk of toxin presence and the possibility of producing bioactive compounds from these microorganisms (Kaul, Gupta, Ahmed, \& Dhar, 2012; Mussi-Dias, Araújo, Silveira, Rocabado, \& Araújo, 2012).

There was no significant effect of the interaction between growth regulators IAA and BAP on bacterial, fungal and oxidation contamination (Table 2). Fungal contamination of $22.81 \%$ at 28 days was higher than on the first evaluation date and corresponded to the percentage of explant discard in this experiment. Mussi-Dias et al. (2012) evaluated fungal endophytic microbiota in eleven species of medicinal plants and found seven different species, and stressed the importance of their presence in the plant without expression of disease sypmtoms.

Another factor that can lead to loss of explants is explant oxidation (Figures 3A and 3B). Final oxidation percentage was 7.6 times higher than initial oxidation at 14 days (Table 2).

There was no rooting of the explants during the 28-day period after use of different concentrations of IAA and BAP. 
Table 2. Bacterial and fungal contamination and oxidation of Malva sylvestris explants at 14 and 28 days of in vitro culture in Murashige and Skoog (MS) medium, at different concentrations of plant growth regulators, 2017

\begin{tabular}{|c|c|c|c|c|c|c|}
\hline \multirow{3}{*}{$\mathrm{BAP}\left(\mathrm{mg} \mathrm{L}^{-1}\right)$} & \multicolumn{6}{|c|}{ IAA $\left(\mathrm{mg} \mathrm{L}^{-1}\right)$} \\
\hline & \multicolumn{3}{|c|}{14 days BC (\%) } & \multicolumn{3}{|c|}{28 days $\mathrm{BC}(\%)$} \\
\hline & 0.0 & 0.5 & Mean & 0.0 & 0.5 & Mean \\
\hline 0 & 28.57 & 33.33 & 31.03 & 37.50 & 53.85 & 47.62 \\
\hline 0.5 & 26.67 & 20.00 & 23.33 & 63.64 & 54.55 & 59.09 \\
\hline 1.0 & 40.00 & 21.42 & 31.03 & 72.72 & 63.64 & 68.18 \\
\hline 1.5 & 40.00 & 23.08 & 32.14 & 61.54 & 70.00 & 65.22 \\
\hline 2.0 & 26.67 & 28.57 & 27.59 & 60.00 & 63.64 & 61.54 \\
\hline \multirow[t]{2}{*}{ Mean } & $32.43^{\mathrm{ns}}$ & $25.35^{\mathrm{ns}}$ & $28.97 \mathrm{~b}$ & $60.34^{\mathrm{ns}}$ & $60.71^{\mathrm{ns}}$ & $60.53 \mathrm{a}$ \\
\hline & \multicolumn{3}{|c|}{14 days $\mathrm{FC}(\%)$} & \multicolumn{3}{|c|}{28 days FC $(\%)$} \\
\hline 0 & 14.29 & 6.67 & 10.34 & 46.67 & 13.33 & 30.00 \\
\hline 0.5 & 13.33 & 13.33 & 13.33 & 26.67 & 20.00 & 23.33 \\
\hline 1.0 & 20.00 & 0.00 & 10.34 & 26.67 & 26.67 & 26.67 \\
\hline 1.5 & 13.33 & 15.38 & 14.28 & 13.33 & 33.33 & 23.33 \\
\hline 2.0 & 6.67 & 14.29 & 10.34 & 0.00 & 21.42 & 10.34 \\
\hline \multirow[t]{2}{*}{ Mean } & $13.51^{\mathrm{ns}}$ & $9.86^{\mathrm{ns}^{-1}}$ & $11.72 \mathrm{~b}$ & $22.67^{\mathrm{ns}}$ & $22.97^{\mathrm{ns}-}$ & $22.81 \mathrm{a}$ \\
\hline & \multicolumn{3}{|c|}{14 days OX $(\%)$} & \multicolumn{3}{|c|}{28 days OX $(\%)$} \\
\hline 0 & 0.00 & 0.00 & 0.00 & 25.00 & 30.77 & 28.57 \\
\hline 0.5 & 0.00 & 6.67 & 3.33 & 0.00 & 18.18 & 9.09 \\
\hline 1.0 & 6.67 & 0.00 & 3.45 & 9.09 & 18.18 & 13.64 \\
\hline 1.5 & 0.00 & 7.69 & 3.57 & 7.69 & 10.00 & 8.70 \\
\hline 2.0 & 0.00 & 0.00 & 0.00 & 13.33 & 27.27 & 19.23 \\
\hline Mean & $1.35^{\mathrm{ns}-}$ & $2.82^{\mathrm{ns}}$ & $2.07 \mathrm{~b}$ & $10.34^{n s}$ & $21.43^{\mathrm{ns}-}$ & $15.79 \mathrm{a}$ \\
\hline
\end{tabular}

Note. Means followed by the same letter in the row of each variable do not differ significantly from each other $(\mathrm{p}$ $\leq 0.05$ ); ns: non-significant; ABA: abscisic acid; IAA: indoleacetic acid; BC: bacterial contamination; FC: fungal contamination; OX: oxidation.

In the experiment with different concentrations of IAA and explant sizes, budding of $M$. sylvestris was detected in the evaluation at 14 days (Figures 4A and 4C). At 28 days, there were completely formed leaves and different root branches (Figures 4B, 4D, 4E, and 4F). 


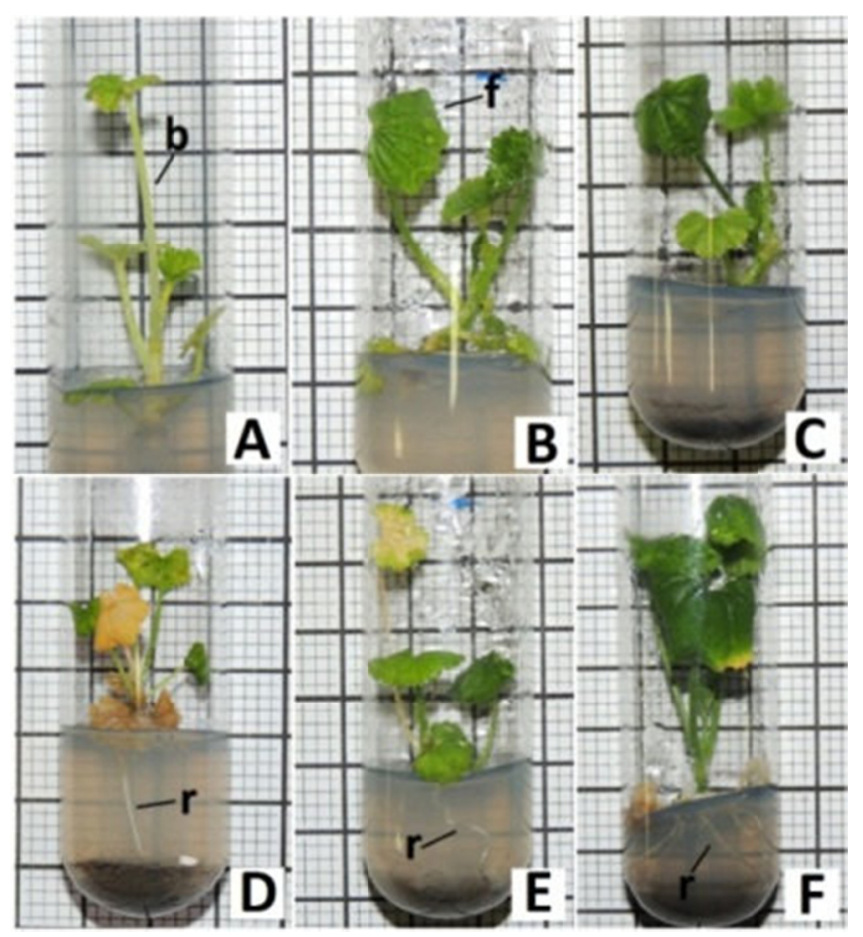

Figure 4. Malva sylvestris explants introduced in vitro in Murashige and Skoog (MS) medium supplemented with different concentrations of growth regulators

Note. After 14 days in vitro (A and C); after 28 days in vitro (B, D, E, F); b, shoot; f, fully formed leaves; r, roots. Smaller and larger squares correspond to 2 and $10 \mathrm{~mm}$, respectively.

At 14 days of in vitro introduction, there was no significant interaction effect between IAA concentrations and different explant sizes for bacterial and fungal contamination. In this period, however, fungal contamination was found to be significantly higher in the larger explants $(48.33 \%)$ than in the smaller ones $(25.56 \%)$, regardless of IAA concentrations (Table 3).

According to Grattapaglia and Machado (1998), larger explants present a greater tendency to in vitro microbial contaminations because there is a greater amount of established ex vitro material; the larger the explant in use, the greater the tendency for disinfectant substances to permeate all regions of the explant, which will hence lead to in vitro contamination more easily (Scherwinski-Pereira, 2010).

There was no difference between explant oxidation and average establishment for either small or large explants (Table 3).

Table 3. Interference of IAA and different explant sizes for contamination, oxidation, establishment and growth of Malva sylvestris after 14 days of in vitro culture in Murashige and Skoog medium, 2017

\begin{tabular}{llllllll}
\hline Size $(\mathrm{mm})$ & $\mathrm{IAA}\left(\mathrm{mg} \mathrm{L}^{-1}\right)$ & $\mathrm{BC}(\%)$ & $\mathrm{FC}(\%)$ & $\mathrm{OX}(\%)$ & $\mathrm{EST}(\%)$ & $\mathrm{BUD}(\mathrm{n})$ & $\mathrm{RGR}^{1}\left(\mathrm{~mm} \mathrm{mmd}^{-1}\right)$ \\
\hline $4-9$ & 0.0 & 43.33 & 16.67 & 13.33 & 76.67 & $3.03 \mathrm{a}$ & 0.021 \\
\hdashline Average & 0.5 & 33.33 & 33.33 & 14.81 & 81.48 & $2.59 \mathrm{a}$ & 0.018 \\
\hline \multirow{2}{*}{$14-23$} & 0.0 & $38.600^{\mathrm{ns}}$ & $25.56 \mathrm{~b}$ & $14.03^{\mathrm{ns}}$ & 78.95 & 2.82 & $0.020 \mathrm{a}$ \\
\hline Average & 0.5 & 22.58 & 44.83 & 20.69 & 75.86 & $2.41 \mathrm{~b}$ & 0.012 \\
\hline
\end{tabular}

Note. Means followed by the same letter in the column of each variable do not differ significantly from each other ( $\mathrm{p} \leq 0.05)$; ns: non-significant $(\mathrm{p} \leq 0.05)$. SIZE: size; IAA: indoleacetic acid; BC: bacterial contamination; FC: fungal contamination; OX: oxidation; EST: establishment; BUD: budding; RGR: relative growth rate; 1 transformed variable (lambda $=0.3$ ). 
There was a significant effect of the interaction between IAA concentrations and explant size for the budding variable. The use of $0.5 \mathrm{mg} \mathrm{L}^{-1}$ of IAA favored an increase in the number of shoots per explant when segments of 14 to $23 \mathrm{~mm}$ were used.

Relative growth rate was higher for small explants (4 to $9 \mathrm{~mm}$ ) than for large (14 to $23 \mathrm{~mm}$ ) explants in this first evaluation period.

At 28 days, $55.74 \%$ of the large explants and $41.07 \%$ of the small explants were discarded. In the remaining explants, it was found that $100 \%$ and $86.11 \%$ of the larger and smaller ones, respectively, were established, with a rooting rate of $12.5 \%$ for the largest and $2.78 \%$ for the smaller ones (Table 4). Filter, Freitas and Périco (2014) reported success with BAP and NAA (naphthaleneacetic acid) for micropropagation of M. sylvestris, but without rooting of explants. In the present research, there was more callus formation when small explants $(58.33 \%)$ were used in comparison to large explants (34.35\%).

In our study, it was found that larger explants developed more efficiently in vitro than smaller explants. Number of shoots per explant was found to be higher when explants with 14 to $23 \mathrm{~mm}$ length were used in comparison to explants of 4 to $9 \mathrm{~mm}$.

Table 4. Interference of phytoregulators and different sizes of explants in the establishment and growth of Malva sylvestris explants after 28 days of in vitro culture in Murashige and Skoog medium, 2017

\begin{tabular}{llllllll}
\hline Size $(\mathrm{mm})$ & IAA $\left(\mathrm{mg} \mathrm{L}^{-1}\right)$ & DISC $(\%)$ & EST $(\%)$ & ROOT $(\%)$ & CALLUS (\%) & BUD (n) & RGR $^{1}\left(\mathrm{~mm} \mathrm{~mm} \mathrm{~d}^{-1}\right)$ \\
\hline $4-9$ & 0.0 & 40.00 & 95.00 & 5.00 & 45.00 & 3.95 & $0.011 \mathrm{~b}$ \\
\hdashline Mean & 0.5 & 42.30 & 75.00 & 0.00 & 75.00 & 3.98 & $0.016 \mathrm{a}$ \\
\hline \multirow{2}{*}{$14-23$} & 0.0 & $41.07^{\mathrm{ns}}$ & $86.11^{\mathrm{ns}}$ & $2.78^{\mathrm{ns}}$ & $58.33 \mathrm{a}$ & $3.69 \mathrm{~b}$ & 0.014 \\
\hdashline Mean & 0.5 & 55.17 & 100.00 & 13.33 & 33.33 & 4.53 & $0.063 \mathrm{a}$ \\
\hline
\end{tabular}

Note. Means followed by the same letter in the column of each variable do not differ significantly from each other ( $\mathrm{p} \leq 0.05$ ); for the RGR variable the comparisons refer to the different levels of IAA in each size; ns: non-significant ( $\mathrm{p} \leq$ 0.05); TAM: size; IAA: indoleacetic acid; DISC: discard; EST: establishment; ROOT: rooting; BUD: budding; RGR: relative growth rate; 1 : transformed variable (lambda $=0.12$ ).

For in vitro establishment of mallow, an interaction occurred $(\mathrm{p} \leq 0.05)$ between the IAA concentrations and the RGR values. It was found that IAA stimulated faster tissue growth in explants that were 4 to $9 \mathrm{~mm}$ in length, but the same effect did not occur in the larger explants.

Souza, Schuch, da Silva, Ferri, and Soares (2007) also found that larger explants of Brazilian cherry (Eugenia uniflora, Myrtaceae) presented better in vitro establishment and development results than smaller explants. According to Hartmann, Kester, and Davies (1990), larger explants usually present larger amounts of nutritional reserves, especially in the form of complex or easily assimilated carbohydrates, which can favor the greater or more rapid development in the establishment in vitro.

The present data showed that when aiming to develop the protocol of in vitro production of M. sylvestris by organogenesis, one should choose to introduce larger explants, because they produce a greater number of shoots more quickly. On the other hand, if one's objective is to develop the protocol by embryogenesis, one should use of smaller explants, since they develop $70 \%$ more calluses when compared to larger explants.

\section{Conclusion}

Micropropagation of $M$. sylvestris is viable and occurs the development of shoot and root of the plant.

Explant size influences the development of M. sylvestris. The use of explants of 4 to $9 \mathrm{~mm}$ allows greater formation of calluses and explants with a size ranging from 14 to $23 \mathrm{~mm}$ produce a greater number of shoots.

The addition of $0.5 \mathrm{mg} \mathrm{L}^{-1}$ IAA in the MS medium positively affects the plant growth rate of the small explants, which was similar to that of the large ones, at 28 days.

\section{Acknowledgements}

To FAPESC through the Rede Guarani Serra Geral/TO 2015TR1067 project and to Programa UNIEDU de Pós-graduação for the scholarship granted to the first author. 


\section{References}

Agrios, G. N. (2005). Plant Pathology (5th ed.). Burlington, MA: Elsevier Academic Press. https://doi.org/ 10.1016/B978-0-08-047378-9.50011-7

Barros, L., Carvalho, A. M., \& Ferreira, I. C. F. R. (2010). Leaves, flowers, immature fruits and leafy flowered stems of Malva sylvestris: A comparative study of the nutraceutical potential and composition. Food and Chemical Toxicology, 48, 1466-1472. https://doi.org/10.1016/j.fct.2010.03.012

Benso, B., Franchin, M., Massarioli, A. P., Paschoal, J. A. R., Alencar, S. M., Franco, G. C. N., \& Rosalen, P. L. (2016). Anti-inflammatory, anti-osteoclastogenic and antioxidant effects of Malva sylvestris extract and fractions: in vitro and in vivo studies. PLoS One, 11(9). https://doi.org/10.1371/journal.pone.0162728

Brasil. (2000). Farmacopeia Brasileira (4nd ed.). São Paulo, SP: Atheneu Editora.

Brasil. (2011). Formulário de Fitoterápicos da Farmacopéia Brasileira. Agência Nacional de Vigilância Sanitária, Brasília, DF.

Briggs, G. E., Kid, F., \& West, C. (1920). A quantitative analysis of plant growth. Annals of Applied Biology, 7, 202-223. https://doi.org/10.1111/j.1744-7348.1920.tb05107.x

Embrapa (Empresa Brasileira de Pesquisa Agropecuária). (2015). Orientações Técnicas para o Cultivo de Plantas Medicinais, Aromáticas e Condimentares. Circular Técnica (Infoteca-E). Retrieved from http://www. infoteca.cnptia.embrapa.br/infoteca/handle/doc/1028982

Filter, M., Freitas, E. M., \& Périco, E. (2014). Influência de diferentes concentrações dos fitorreguladores ácido 6-benzilaminopurina e ácido naftalenoacético na propagação vegetativa de Malva sylvestris L. Revista Brasileira de Plantas Medicinais, 16(1), 47-53. https://doi.org/10.1590/S1516-05722014000100007

Gavériaux, J. P. (1872). Puccinia malvacearum Montagne responsable de larouille de la rose trémière [Althea rosea (L.) Cav.]. Societé Mycologique du Nord de la France, 90, 13-19.

Grattapaglia, D., \& Machado, M. A. (1998). Micropropagação. In A. C. Torres, L. S. Caldas, \& J. A. Buso (Eds.), Cultura de tecidos e transformação genética de plantas. Brasília, DF: SPI/Embrapa-CNPH.

Hartmann, H. T. M., Kester, D. E., \& Davies Jr., F. T., (1990). Plant propagation: Principles and practices (5nd ed.). Englewood Cliffs, NJ: Prentice Hall.

Hothorn, T., Bretz, F., \& Westfall, P. (2008). Simultaneous inference in general parametric models. Biometrical Journal, 50(3), 346-363. https://doi.org/10.1002/bimj.200810425

Kaul, S., Gupta, S., Ahmed, M., \& Dhar, M. K. (2012). Endophytic fungi from medicinal plants: A treasure hunt for bioactive metabolites. Phytochem Reviews, 11(4), 487-505. https://doi.org/10.1007/s11101-0129260-6

Khatami, F., \& Ghanati, F. (2011). Effects of UV irradiation on cell viability, anthocyanin, and flavonoid contents of callus-cultured Malva neglecta cells. International Conference on Life Science and Technology, 3, 198-201.

Kintzios, S. E. (2002). Malva sp. (Mallow): In vitro culture and the production of secondary metabolites. In T. Nagata, \& Y. Ebizuka (Eds.), Medicinal and AromaticPlants XII: Biotechnology in Agriculture and Forestry 51. https://doi.org/10.1007/978-3-662-08616-2_2

Kintzios, S. E., Katsouri, E., Peppes, D., \& Koulocheri, S. (1998). Somatic embryogenesis and in vitro secondary metabolite production from common mallow (Malva sylvestris L.) collected in Greece. Acta Horticulturae, 457, 173-179. https://doi.org/10.17660/ActaHortic.1998.457.21

Kuvalekar, A. A., \& Gandhe, R. (2010). Associated callus culture technique for in vitro growth of rust fungi. Journal of Threatened Taxa, 2(9), 1140-1143. https://doi.org/10.11609/JoTT.o2263.1140-3

Marouane, W., Soussi, A., Murat, J., Bezzine, S., \& El Feki, A. (2011). The protective effect of Malva sylvestris on rat kidney damaged by vanadium. Lipids in Health and Disease, 10(65), 10-65. https://doi.org/ 10.1186/1476-511X-10-65

Murashige, T., \& Skoog, F. (1962). A revised médium for rapid growth and bioassay with tobacco tissue cultures. Physiologia Plantarum, 15(4), 473-497. https://doi.org/10.1111/j.1399-3054.1962.tb08052.x

Mussi-Dias, V., Araújo, A. C. O., Silveira, S. F., Rocabado, J. M. A., \& Araújo, K. L. (2012). Fungos endofíticos associados a plantas medicinais. Revista Brasileira de Plantas Medicinais, 14(2), 261-266. https://doi.org/ $10.1590 / \mathrm{S} 1516-05722012000200002$ 
Pirbalouti, A. G., Yousefi, M., Nazari, H., Karimi, I., \& Koohpayeh, A. (2009). Evaluation of burn healing properties of Arnebia euchroma and Malva sylvestris. Electronic Journal of Biology, 5(3), 62-66.

Prudente, A., Sponchiado, G., Mendes, D. A., Soley, B., Cabrini, D., \& Otuki, M. (2017). Pre-clinical efficacy assessment of Malva sylvestris on chronic skin inflammation. Biomedicine \& Pharmacotherapy, 93, 852-860. https://doi.org/10.1016/j.biopha.2017.06.083

$\mathrm{R}$ Core Team. (2017). R: A language and environment for statistical computing. R Foundation for Statistical Computing.

Ray, S., \& Ali, N. (2017). Biotic Contamination and Possible Ways of Sterilization: A Review with Reference to Bamboo Micropropagation. Brazilian Archives of biology and technology, 60.

Rout, G. R., Samantaray, S., \& Das, P. (2000). In vitro manipulation and propagation of medicinal plants. Biotechnology Advances, 18, 91-120. https://doi.org/10.1016/S0734-9750(99)00026-9

Scherwinski-Pereira, J. E. (2010). Contaminações microbianas na cultura de células, tecidos e órgãos de plantas. Brasília, DF: Embrapa Informação Tecnológica.

Souza, J. A., Schuch, M. W., da Silva, L. C., Ferri, J., \& Soares, G. C. (2007). Solidificante no meio de cultura e tamanho do explante no estabelecimento da propagação in vitro de pitangueira (Eugenia uniflora L.). Revista Brasileira de Agrociência, 13(1), 115-118.

Tabaraki, R., Yosefi, Z., \& Hossein, A. G. (2012). Chemical composition and antioxidant properties of Malva sylvestris. Journal of Research in Agricultural Science, 8(1), 59-68.

Tomoda, M., Gonda, R., Shimizu, N., \& Yamada, H. (1989). Plant Mucilages. XLII. An anti-complentary mucilage from leaves of Malva sylvestris var. mauritiana. Chemical and Pharmaceutical Bulletin, 37(11), 3029-3032. https://doi.org/10.1248/cpb.37.3029

Tyub, S., Kamili, A. N., \& Bhat, M. M. (2016). In vitro propagation of Althaea rosea: A valuable medicinal plant of Kashmir Himalaya. Journal of Nature and Natural Sciences, 1(5), 1-4. https://doi.org/10.26859/jnnsci. v1i01.9596

Yano, I., Nichols, B. W., Morris, L. J., \& James, A. T. (1972). The distribution of cyclopropane and cyclopropene fatty acids in higher plants (Malvaceae). Lipids, 7(1), 30-34. https://doi.org/10.1007/BF 02531266

\section{Copyrights}

Copyright for this article is retained by the author(s), with first publication rights granted to the journal.

This is an open-access article distributed under the terms and conditions of the Creative Commons Attribution license (http://creativecommons.org/licenses/by/4.0/). 